\title{
Synthesis of ZSM-5/Porous Mullite Honeycomb Composite from Sintered Malaysia Kaolin via Hydrothermal Processing
}

\author{
Hiroaki KATSUKI, Nobuaki KAMOCHI and Sridhar KOMARNENI* \\ Saga Ceramics Research Laboratory, 3037-7, Arita-machi, Saga 844-0024 \\ * Materials Research Laboratory and Department of Agronomy, The Pennsylvania State University, \\ University Park, Pennsylvania 16802-4801, U.S.A.
}

\section{マレーシアカオリン焼結体の水熱処理によるZSM-5/多孔質ムライトハニカム複合体の合成 勝木宏昭·蒲池伸明·Sridhar Komarneni* \\ 佐賀県䅁業技術センター, 844-0024 佐賀県西松浦郡有田町 3037-7 \\ *Materials Research Laboratory and Department of Agronomy, The Pennsylvania State University, University Park, Pennsylvania 16802-4801, U.S.A.}

\begin{abstract}
The synthesis and properties of ZSM-5 film on a porous mullite honeycomb have been investigated using Malaysia kaolin. Amorphous silica-glass in the kaolin honeycomb sintered at $1450^{\circ} \mathrm{C}$ was used as a source for ZSM-5 formation. The honeycomb was hydrothermally treated in $\mathrm{NaOH}$, tetrapropylammonium bromide, and water to prepare a novel ZSM-5/mullite honeycomb composite via in-situ crystallization at 160 to $180^{\circ} \mathrm{C}$. This paper describes the formation of mullite from Malaysia kaolin at 1400 to $1500^{\circ} \mathrm{C}$, the effects of hydrothermal conditions such as reaction temperature, time, and concentration of $\mathrm{NaOH}$ solution on the formation of ZSM-5 crystals on the honeycomb, and on the porous properties of the composite.
\end{abstract}

[Received August 4, 2000; Accepted September 20, 2000]

Key-words : Kaolin, ZSM-5 zeolite, Silica-glass, Mullite, Hydrothermal treatment

1. Introduction

ZSM-5 type zeolite has a three-dimensional channel system where straight channels run along the [010] direction and have pore of $0.54 \mathrm{~nm} \times 0.56 \mathrm{~nm}$, defined by 10 -membered rings of tetrahedral. The basic features of this structure are independent of the $\mathrm{Si}: \mathrm{Al}$ ratio and also shown by silicalite, the silica end-member of the ZSM- 5 compositional series. ${ }^{1), 2)}$ ZSM-5 type zeolite are very useful materials as catalyst supports for the synthesis of organic and inorganic chemicals and for $\mathrm{NO}_{x}$ decomposition. ${ }^{3-6)}$ In recent years, thin and dense ZSM-5 and silicalite membranes on macroporous ceramic supports have been investigated for use as gas-separation and permeation materials because of their high chemical and thermal stability as well as their molecular-sieving characteristics. ${ }^{7-11}$ ) In these reports, ZSM-5 or silicalite crystals were hydrothermally prepared at 120 to $180^{\circ} \mathrm{C}$ using colloidal silica as a source of ZSM-5. In our previous studies, we used the sintered New Zealand kaolin as a starting material for ZSM-5 film. ${ }^{12), 13)}$ The sintered New Zealand kaolin at $1650^{\circ} \mathrm{C}$ was composed of 42 mass $\%$ silica-glass and 58 mass $\%$ mullite. Silica-glass is easily dissolved in $\mathrm{NaOH}$ solution, but mullite is a very stable phase. By using this solubility difference in $\mathrm{NaOH}$ solution, the silica-glass in the sintered kaolin could be used as a $\mathrm{SiO}_{2}$ source for ZSM-5 via a hydrothermal reaction. However, the New Zealand kaolin needed high sintering temperatures, ca. 1600 to $1650^{\circ} \mathrm{C}$, to form amorphous silica and mullite because of lower content of $\mathrm{Na}_{2} \mathrm{O}$ and $\mathrm{K}_{2} \mathrm{O}$ which act as a flux. ${ }^{14)}$ Furthermore, the formation of ZSM-5 crystals on the sintered kaolin honeycomb required higher temperature $\left(190^{\circ} \mathrm{C}\right.$ ) and longer reaction time ( 1 to 3 weeks) via hydrothermal processing using New Zealand kaolin.

To reduce the sintering temperature of kaolin, hydrothermal temperature, and reaction time, Malaysia kaolin containing higher $\mathrm{Na}_{2} \mathrm{O}$ and $\mathrm{K}_{2} \mathrm{O}$ contents was used as a source for ZSM- 5 crystals in this study. This paper describes the formation of mullite and silica-glass from Malaysia kaolin, and the effect of hydrothermal conditions and some charac- teristics of ZSM-5/porous mullite composites.

\section{Experimental procedure}

2.1 Synthesis of ZSM-5/porous mullite composite

Malaysia kaolin was used as a starting material for the ZSM-5/mullite composite. The chemical composition of the kaolin powder is as follows: Loss on Ignition: $13.56, \mathrm{SiO}_{2}$ : 45.43, $\mathrm{Al}_{2} \mathrm{O}_{3}: 38.50, \mathrm{Fe}_{2} \mathrm{O}_{3}: 0.78, \mathrm{TiO}_{2}: 0.20, \mathrm{CaO}: 0.03$, $\mathrm{MgO}: 0.08, \mathrm{Na}_{2} \mathrm{O}: 0.38, \mathrm{~K}_{2} \mathrm{O}: 0.93$ (all in mass\%). The major mineral phase is kaolinite and minor phases are quartz, gibbsite and muscovite. The kaolin powder was calcined at $900^{\circ} \mathrm{C}$ for $1 \mathrm{~h}$ to dehydrate and remove structural water. After calcination, a binder (methyl cellulose, 10 mass $\%$ ) and kaolin powder were well mixed with water (25 mass $\%$ ) for $1 \mathrm{~h}$ before extrusion. The size of the extruded honeycomb monolith was $18 \mathrm{~mm} \times 18 \mathrm{~mm} \times 10 \mathrm{~mm}$ and the cell size and wall thickness were $1.5 \mathrm{~mm} \times 1.5 \mathrm{~mm}$ and $500 \mu \mathrm{m}$, respectively. The kaolin honeycombs were sintered at 1400 , 1450 and $1500^{\circ} \mathrm{C}$ for $2 \mathrm{~h}$ to investigate the formation of mullite crystals and silica-glass as a source of ZSM-5 crystals.

A reactant mixture composed of the sintered kaolin honeycomb, $\mathrm{NaOH}$, tetrapropylammonium bromide (TPABr) for the template, and deionized water was placed in a double-walled vessel where the inner vessel was made of Teflon and the outer vessel was made of stainless steel. The volume of the Teflon vessel was $100 \mathrm{ml}$. The vessel was introduced into a drying oven that was preheated at $160^{\circ} \mathrm{C}$, and it was held for 2 to $14 \mathrm{~d}$. After hydrothermal treatment, the honeycomb was thoroughly washed with hot water several times and stored at $120^{\circ} \mathrm{C}$. The molar composition of the raw materials was $100 \mathrm{SiO}_{2}$ (in the sintered kaolin): (12.8 or 25.5 ) NaOH: 5TPABr: $2800 \mathrm{H}_{2} \mathrm{O}$. In this case, $\mathrm{SiO}_{2}$ indicates amorphous silica in the sintered kaolin honeycomb.

2.2 Characterization of the sintered kaolin and ZSM-5/porous mullite composite

The morphology and crystal structure of the sintered kaolin at 1400 to $1500^{\circ} \mathrm{C}$ was characterized by scanning electron 
microscopy (SEM, JXA-840, JEOL Co.) and by powder Xray diffractometry (XRD, RAD-2B, Rigaku Co.) with $\mathrm{Cu}$ $\mathrm{K} \alpha$ radiation. To calculate the amount of silica-glass and mullite in the sintered kaolin by XRD, the calibration line was made with the commercial mullite (IJOA, Showa Denko Co., Ltd.) and the Ca stabilized $\mathrm{ZrO}_{2}$ (hereafter referred to as $\mathrm{Ca}-\mathrm{ZrO}_{2}, \mathrm{CSZ}-15$, Daiichi Kigenso Co., Ltd.) and amorphous silica gel (Wakogel C-300, Wako Pure Chemical Ind., Ltd.) as diluents. The amount of mullite and silica-glass was calculated from the change of intensity ratio of mullite $\{(120)+(210)\} / \mathrm{Ca}-\mathrm{ZrO}_{2}$ (111). The commercial mullite powder was fired at $1600^{\circ} \mathrm{C}$ for $2 \mathrm{~h}$ and then ground by an agate mortar. Particle size of mullite powder after grinding was 1 to $3 \mu \mathrm{m}$.

After hydrothermal treatment, the honeycomb coated with zeolite film and zeolite film precipitated on the Teflon vessel were collected separately and washed thoroughly with hot water, and then dried at $120^{\circ} \mathrm{C}$. Samples were calcined at $550^{\circ} \mathrm{C}$ for $13 \mathrm{~h}$ to remove the TPABr from the zeolite framework. The conversions of raw silica-glass in the sintered kaolin to zeolite films that were formed on the honeycomb and on the Teflon vessel were calculated. The characteristics of zeolites were evaluated by SEM and XRD. The surface area and micropore distribution of the zeolite film formed on the Teflon vessel were measured by the BET method with nitrogen- and argon-gas as the adsorbent (Autosorb-1, Quantachrome Co. and BELSORP28SA, Japan Bell Co.), respectively, after degassing at $300^{\circ} \mathrm{C}$ for $2 \mathrm{~h}$. Porous properties of zeolite film was compared with that of commercial ZSM-5 type zeolite powder (HSZ-840NHA, $\mathrm{SiO}_{2} /$ $\mathrm{Al}_{2} \mathrm{O}_{3}=39$ in molar ratio, $\mathrm{Na}_{2} \mathrm{O}<0.01$ mass \%, Loss on $\mathrm{Ig}$.: 6.5 mass $\%$, BET surface area: $242.3 \mathrm{~m}^{2} / \mathrm{g}$, pore volume: $0.147 \mathrm{~cm}^{3} / \mathrm{g}$, Toso Co., Ltd.). The $\mathrm{SiO}_{2}: \mathrm{Al}_{2} \mathrm{O}_{3}$ molar ratio and the chemical composition of the zeolite film formed on the Teflon vessel were measured by X-ray fluorescent spectrometry (Model 3070, Rigaku Co.).

\section{Results and discussion}

3.1 Formation of silica-glass and mullite from Malaysia kaolin

The formation temperature of mullite from kaolinite was reported previously to occur at lower temperatures than halloysite. ${ }^{15)}$ Figures 1 and 2 show the morphology and XRD patterns of the fired Malaysia kaolin honeycomb at 1400,1450 , and $1500^{\circ} \mathrm{C}$ for $2 \mathrm{~h}$ to study the effect of sinter- ing temperature on the formation of silica-glass and mullite. To observe mullite crystals in the sintered kaolin, the fired
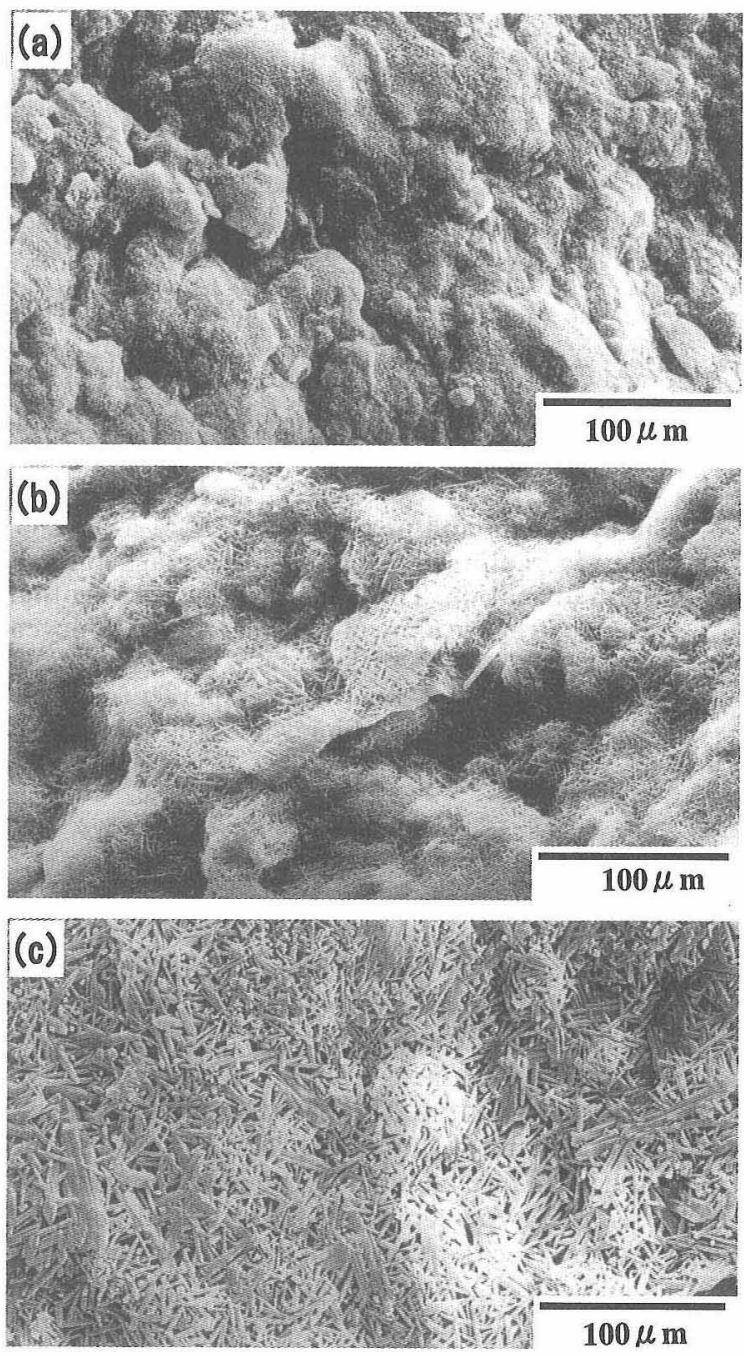

Fig. 1. Morphology of mullite crystals formed in Malaysia kaolin honeycomb sintered at (a) 1400 , (b) 1450 and (c) $1500^{\circ} \mathrm{C}$

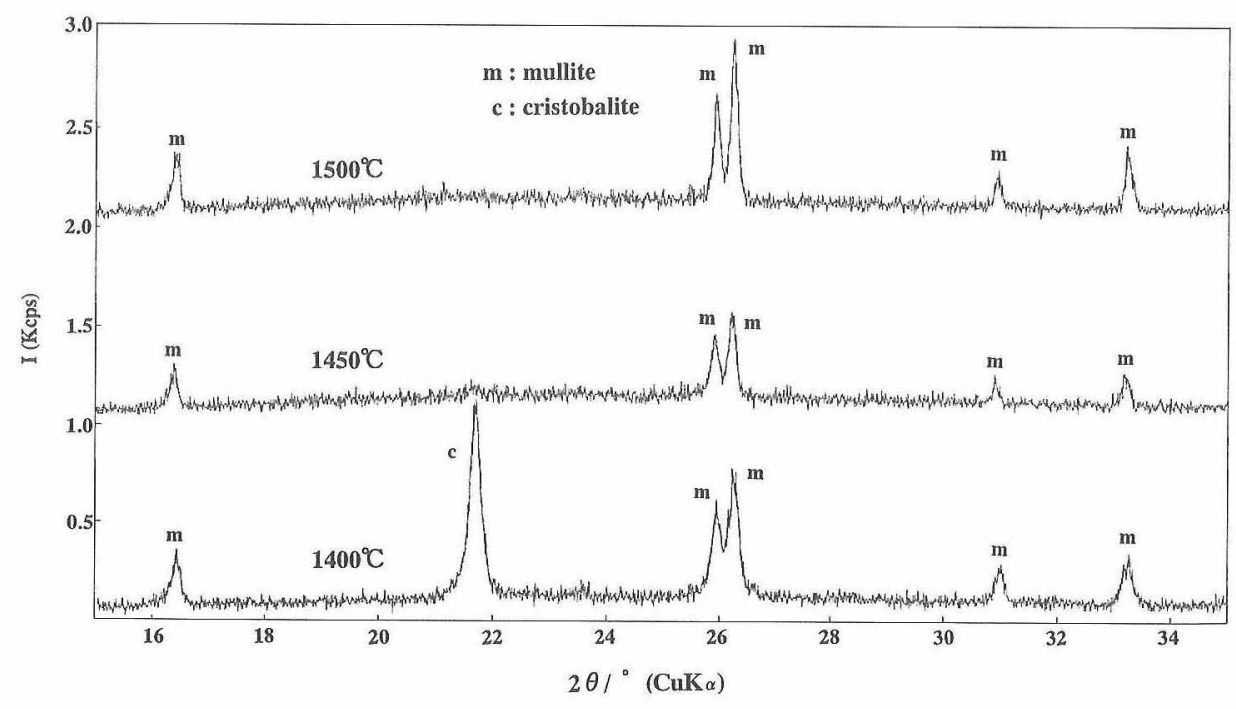

Fig. 2. XRD patterns of Malaysia kaolin honeycomb sintered at 1400,1450 and $1500^{\circ} \mathrm{C}$. 
samples were treated with $4.6 \% \mathrm{HF}$ solution for $1 \mathrm{~h}$ to dissolve silica-glass. At $1400^{\circ} \mathrm{C}$, crystal phases were mullite, $\alpha$ cristobalite and silica-glass (as revealed by noise) by XRD, and fine mullite crystals which are less than $1 \mu \mathrm{m}$ long were formed. $\alpha$-cristobalite completely melted and the formation of mullite was promoted above $1450^{\circ} \mathrm{C}$. The crystal sizes of mullite at 1450 and $1500^{\circ} \mathrm{C}$ were 1 to $2 \mu \mathrm{m}$ long and 2 to 5 $\mu \mathrm{m}$ long, respectively. The proportions of silica-glass and mullite were 43 to 48 mass $\%$ and 52 to 57 mass $\%$, respectively at $14500^{\circ} \mathrm{C}$, and 38 to 41 mass $\%$ and 59 to 62 mass $\%$, respectively at $1500^{\circ} \mathrm{C}$. In the case of this Malaysia kaolin, ideal proportions of silica-glass and mullite were expected to be 35 and 65 mass \% if aluminum source could be completely converted to mullite after sintering. Based on this assumption, it appears that unreacted aluminum source to the extent of 6 to 9 mass $\%$ of the kaolin existed in the silicaglass phase at $1450^{\circ} \mathrm{C}$. In our previous study, ${ }^{14)}$ the formation of mullite from New Zealand kaolin was promoted above $1600^{\circ} \mathrm{C}$ because of lower content of $\mathrm{Na}_{2} \mathrm{O}$ and $\mathrm{K}_{2} \mathrm{O}$ which act as a flux for the formation of silica-glass. Because of higher $\mathrm{Na}_{2} \mathrm{O}$ and $\mathrm{K}_{2} \mathrm{O}$ content, lower sintering temperature was needed for Malaysia kaolin and therefore, it is expected to be one of very useful raw materials for ZSM-5 synthesis.

3.2 Effect of hydrothermal conditions on the formation of ZSM-5/mullite composite

The control of the dissolution of the silica-glass from the sintered honeycomb in this study is a very important initial process to prepare ZSM-5 film on the honeycomb surface. To investigate the formation of ZSM-5, the honeycomb sintered at $1450^{\circ} \mathrm{C}$ was used and first treated hydrothermally at $160^{\circ} \mathrm{C}$ for 2 to $14 \mathrm{~d}$ with the molar ratio composition of $100 \mathrm{SiO}_{2}:(12.8$ or 25.5$) \mathrm{NaOH}: 5 \mathrm{TPABr}: 2800 \mathrm{H}_{2} \mathrm{O}$. The $\mathrm{SiO}_{2}$ is from sintered kaolin. The concentration of 12.8 and $25.5 \mathrm{NaOH}$ solution is equal to 0.25 and $0.5 \mathrm{~mol} / 1$ of $\mathrm{NaOH}$, respectively.

Figures 3 and 4 show the XRD results and the morphology for the honeycomb treated in $25.5 \mathrm{NaOH}$ solution at 160 ${ }^{\circ} \mathrm{C}$ for 2 to $7 \mathrm{~d}$. XRD and SEM showed that continuous ZSM-5 type zeolite film, composed of round-shaped ZSM-5 crystals of 20 to $50 \mu \mathrm{m}$ in diameter (Fig. 4(a)) and cubicshaped crystals of 5 to $20 \mu \mathrm{m}$ long (Fig. 4(c), could be formed on the honeycomb in 2 to $7 \mathrm{~d}$. Furthermore, the honeycomb was treated in $12.8 \mathrm{NaOH}$ solution at $160^{\circ} \mathrm{C}$ for 2 to $14 \mathrm{~d}$. The continuous ZSM-5 zeolite films, composed of well-crystallized, cubic-shaped crystals, were formed after treatment for 7 to $14 \mathrm{~d}$. The formation of ZSM- 5 crystals in $12.8 \mathrm{NaOH}$ solution needed longer reaction time compared with that of the formation in $25.5 \mathrm{NaOH}$ because of low dissolution rate of silica-glass. In our previous study, ${ }^{13)}$ it took a long reaction time of 14 to $21 \mathrm{~d}$ at $190^{\circ} \mathrm{C}$ for the formation of ZSM-5 film from the sintered New Zealand kaolin at 1650 ${ }^{\circ} \mathrm{C}$, but by using Malaysia kaolin here, the sintering temperature of kaolin and hydrothermal temperature and time of ZSM-5 formation were reduced.

Table 1 shows the effect of hydrothermal conditions on the formation of ZSM-5 crystals on the honeycomb and on the Teflon vessel, and the residual silica in the honeycomb and liquid. In the case of treatment with $12.8 \mathrm{NaOH}$ for 2 to $4 \mathrm{~d}$, the dissolution of silica-glass from the honeycomb was small, i.e., 93.4 to 83.4 mass \% silica-glass remained in the honeycomb body. The conversion of the silica source to ZSM-5 crystals on the honeycomb was 6.6 to 14.3 mass \% for 2 to $4 \mathrm{~d}$. With increased reaction time, the conversion to ZSM-5 crystals on the honeycomb reached 25.5 and 51.8 mass $\%$ after 7 and $14 \mathrm{~d}$, respectively. The dissolution of silica-glass from the honeycomb was promoted in $25.5 \mathrm{NaOH}$ solution, and the conversion to ZSM-5 crystals on the honeycomb was 27.9 mass $\%$ after $2 \mathrm{~d}$. With increasing reaction time, the conversion of silica-glass to ZSM-5 crystals on the honeycomb increased to 41.8 to 56.6 mass\%, but its deposition on the Teflon vessel was at most 2 to 6 mass\%. From the observation of polished cross-section of the honeycomb treated in $25.5 \mathrm{NaOH}$ for 4 to $7 \mathrm{~d}$, the thickness of continuous ZSM-5 film was 100 to $120 \mu \mathrm{m}$ as shown in Fig. 5. Furthermore, we confirmed that the honeycombs shown in Fig. 5 were composed of four layers from the surface to the core, as follows: (1) ZSM-5 crystals on the top surface; (2) ZSM-5 and mullite below the top surface; (3) porous mullite; and (4) mullite and silica-glass at the core. ZSM-5/porous mullite honeycomb composite with these four layers was previously reported from the sintered New Zealand kaolin honeycomb at $190^{\circ} \mathrm{C}$ for 14 d. ${ }^{13)}$ However, the results reported here are at lower temperature compared to the previous study because of compositional differences between the two kaolins used.

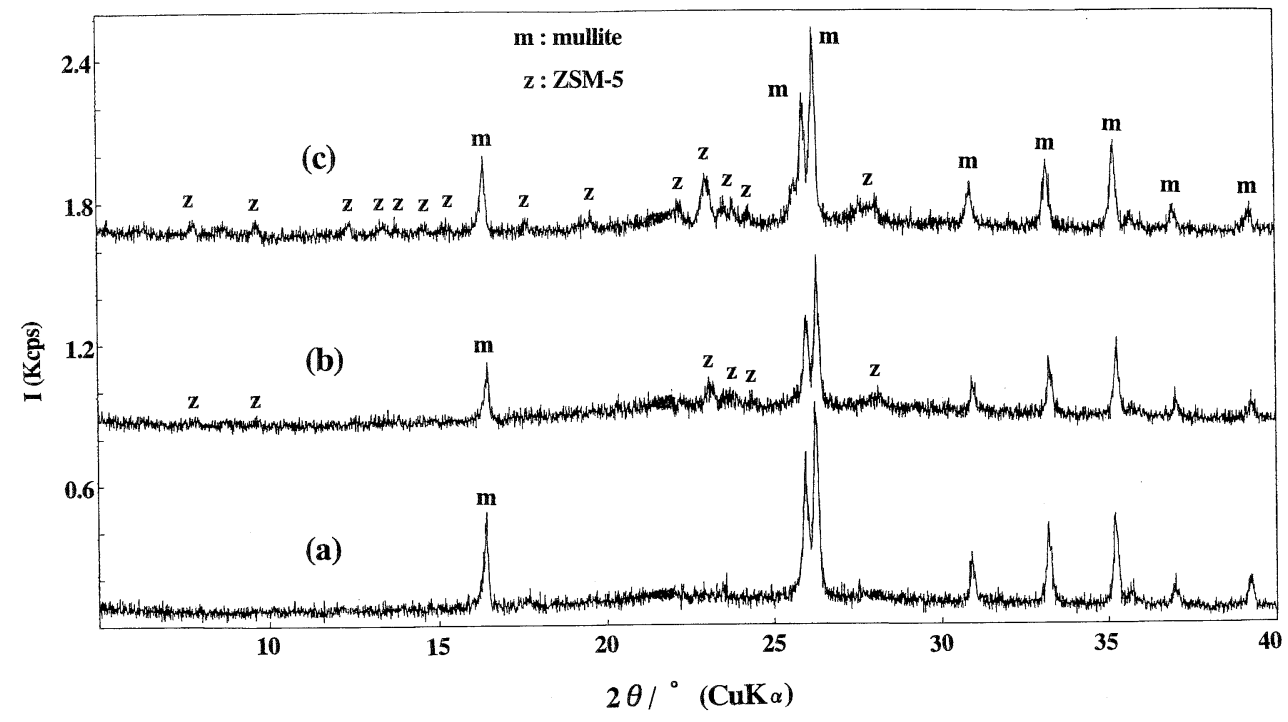

Fig. 3. XRD patterns of ZSM-5/porous mullite honeycomb composite at $160^{\circ} \mathrm{C}$ for (a) $2 \mathrm{~d}$, (b) $4 \mathrm{~d}$ and (c) $7 \mathrm{~d}$ with a composition of $100 \mathrm{SiO}_{2}: 25.5 \mathrm{NaOH}: 5 \mathrm{TPABr}: 2800 \mathrm{H}_{2} \mathrm{O}$. 
Table 1. Conversion of Silica-Glass in the Sintered Kaolin Honeycomb to ZSM-5 Zeolite Crystals*

\begin{tabular}{|c|c|c|c|c|c|}
\hline \multirow{2}{*}{$\begin{array}{c}\text { Temperature } \\
\text { (ㄷ) }\end{array}$} & \multirow{2}{*}{$\begin{array}{l}\text { Time } \\
\text { (days) }\end{array}$} & \multirow{2}{*}{$\begin{array}{l}\mathrm{NaOH} \\
(\mathrm{X})\end{array}$} & \multicolumn{2}{|c|}{ Conversion of silica to ZSM-5 (\%) } & \multirow{2}{*}{$\begin{array}{l}\text { Residual silica } \\
\qquad(\%)\end{array}$} \\
\hline & & & Honeycomb & Teflon vessel & \\
\hline 160 & 2 & 12.8 & 6.6 & 0 & 93.4 \\
\hline 160 & 4 & 12.8 & 14.3 & 2.3 & 83.4 \\
\hline 160 & 7 & 12.8 & 25.5 & 8.2 & 66.3 \\
\hline 160 & 14 & 12.8 & 51.8 & 10.3 & 37.9 \\
\hline 160 & 2 & 25.5 & 27.9 & 1.8 & 70.3 \\
\hline 160 & 4 & 25.5 & 41.8 & 2.3 & 55.9 \\
\hline 160 & 7 & 25.5 & 56.6 & 6.2 & 37.2 \\
\hline
\end{tabular}

* Chemical compostition: $100 \mathrm{SiO}_{2}:$ (X)NaOH : $5 \mathrm{TPABr}: 2800 \mathrm{H}_{2} \mathrm{O}$
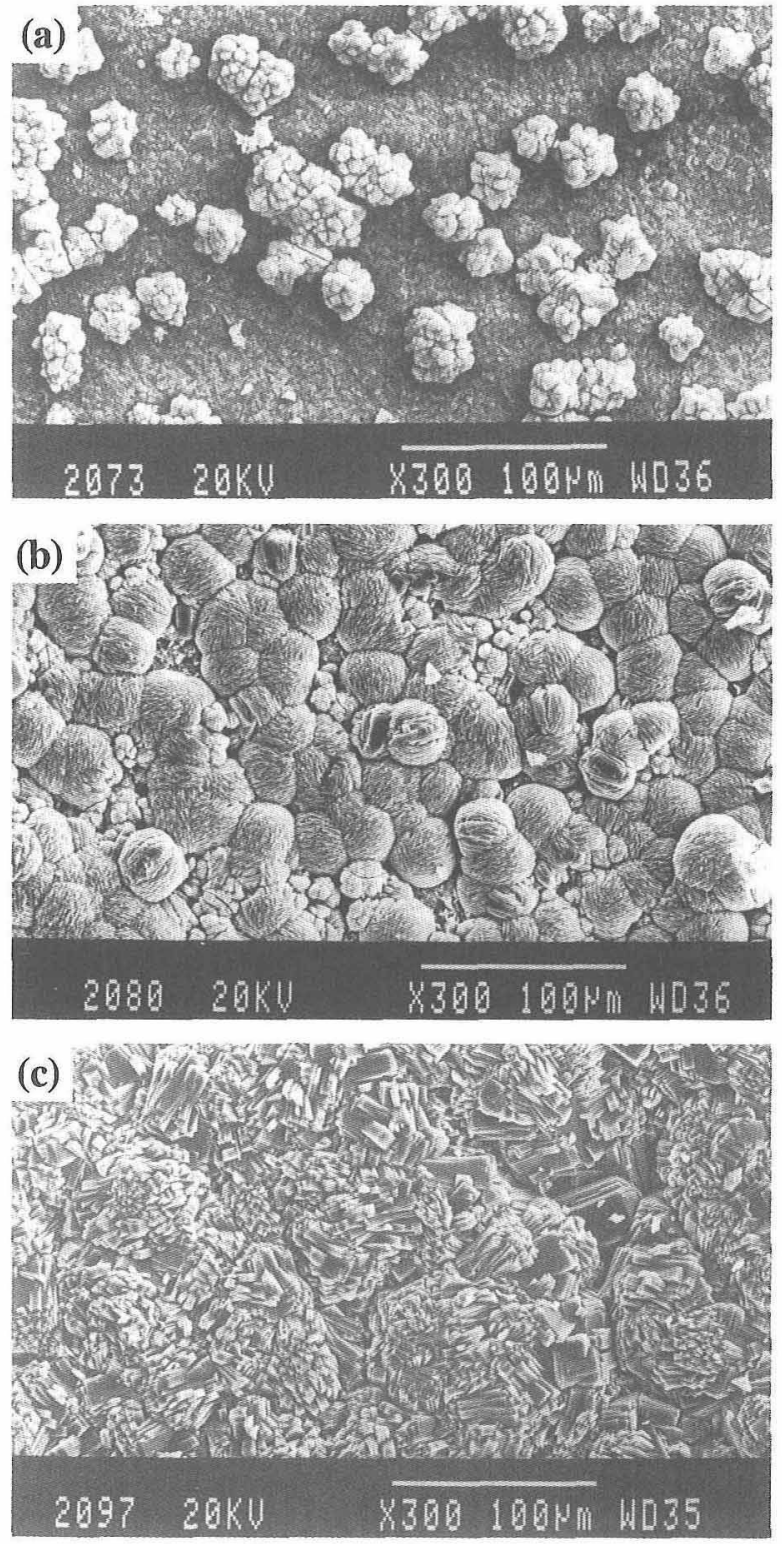

Fig. 4. Morphology of ZSM-5 zeolite crystals formed on the honeycomb surface at $160^{\circ} \mathrm{C}$ for (a) $2 \mathrm{~d}$, (b) $4 \mathrm{~d}$ and (c) $7 \mathrm{~d}$ with a composition of $100 \mathrm{SiO}_{2}: 25.5 \mathrm{NaOH}: 5 \mathrm{TPABr}: 2800 \mathrm{H}_{2} \mathrm{O}$.

3.3 Porous properties and chemical composition of ZSM-5/porous mullite composite

To evaluate the porous properties of ZSM- 5 crystals pre-
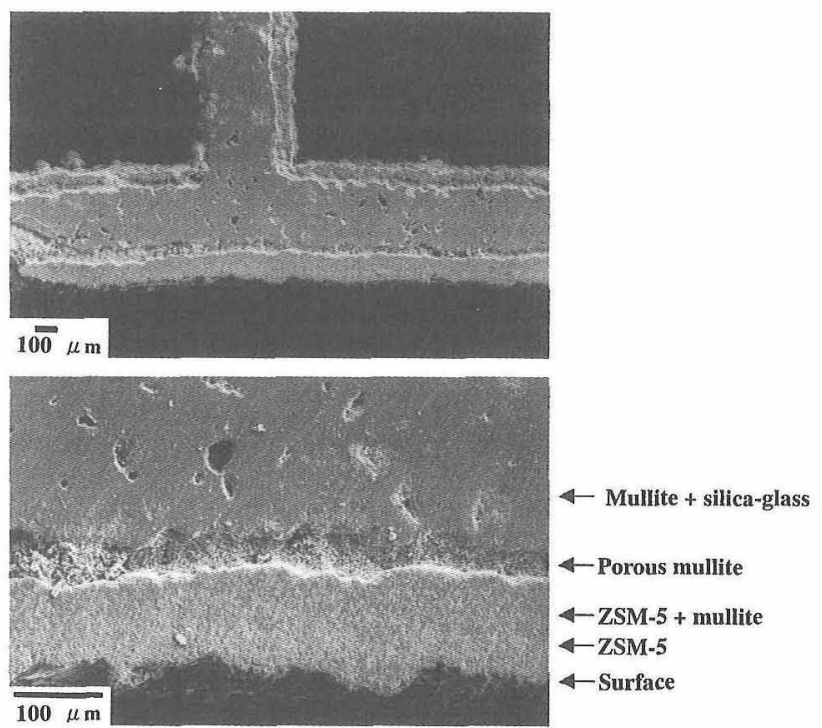

Fig. 5. Polished cross section of the honeycomb coated with ZSM-5 zeolite layer at $160^{\circ} \mathrm{C}$ for $7 \mathrm{~d}$ with a composition of $100 \mathrm{SiO}_{2}$ : $25.5 \mathrm{NaOH}: 5 \mathrm{TPABr}: 2800 \mathrm{H}_{2} \mathrm{O}$.

pared in this study, the porous properties were measured by $\mathrm{N}_{2}$-BET method. Table 2 shows the BET surface area and pore volume of ZSM-5 film formed on the Teflon vessel and the composite. The surface area and pore volume of the ZSM-5 film formed on the vessel were $290-305 \mathrm{~m}^{2} / \mathrm{g}$ and $0.16-0.18 \mathrm{~cm}^{3} / \mathrm{g}$ in $12.8 \mathrm{NaOH}$, and 244 to $260 \mathrm{~m}^{2} / \mathrm{g}$ and $0.14-0.16 \mathrm{~cm}^{3} / \mathrm{g}$ in $25.5 \mathrm{NaOH}$, respectively. Surface areas and pore volumes depended on the hydrothermal conditions. Surface areas decreased in higher concentration of $\mathrm{NaOH}$ solution, the reason for which is not clear at present. However, the surface area of the composites strongly depended on the reaction conditions and changed from 18 to $48 \mathrm{~m}^{2} / \mathrm{g}$. The surface area of the composite was mainly influenced by the amount of ZSM- 5 and unleached silica-glass in the honeycomb as shown in Fig. 5.

Figure 6 shows the micropore distribution of ZSM-5 film formed on the Teflon vessel and the commercial ZSM-5 powder measured by argon gas at $87 \mathrm{~K}$. Micropores of these two ZSM-5 samples are indicated by a type-I argon gas adsorption isotherm, and uniform pore diameter centered at 0.59 to $0.61 \mathrm{~nm}$. These pores are expected, based on the crystal structure of the ZSM-5, i.e., approximately $0.5 \mathrm{~nm}$ in pore diameter. ZSM-5 film formed on the honeycomb showed the same pore size distribution as that of ZSM-5 film formed on the Teflon vessel. Furthermore, there were no differences on the morphology and structure between two 
Table 2. BET Surface Areas and Pore Volume of ZSM-5 Film Precipitated on the Teflon Vessel and ZSM-5/Porous Mullite Honeycomb Composite*

\begin{tabular}{|c|c|c|c|c|c|}
\hline \multirow{2}{*}{$\begin{array}{c}\text { Temperature } \\
\left({ }^{\circ} \mathrm{C}\right)\end{array}$} & \multirow{2}{*}{$\begin{array}{l}\text { Time } \\
\text { (days) }\end{array}$} & \multirow{2}{*}{$\begin{array}{c}\mathrm{NaOH} \\
(\mathbf{X})\end{array}$} & \multicolumn{2}{|c|}{ ZSM-5 film } & \multirow{2}{*}{$\begin{array}{c}\text { Composite } \\
\text { Surface area }\left(\mathrm{m}^{2} / \mathrm{g}\right)\end{array}$} \\
\hline & & & Surface area $\left(\mathrm{m}^{2} / \mathrm{g}\right)$ & Pore volume (cc/g) & \\
\hline 160 & 4 & 12.8 & 289.1 & 0.175 & 8.0 \\
\hline 160 & 7 & 12.8 & 305.4 & 0.169 & 21.6 \\
\hline 160 & 14 & 12.8 & 296.9 & 0.160 & 52.6 \\
\hline 160 & 2 & 25.5 & 250.8 & 0.151 & 28.6 \\
\hline 160 & 4 & 25.5 & 259.1 & 0.143 & 44.5 \\
\hline 160 & 7 & 25.5 & 244.5 & 0.158 & 58.0 \\
\hline
\end{tabular}

*Chemical composition: 100SiO2: (X)NaOH : $5 \mathrm{TPABr}: 2800 \mathrm{H}_{2} \mathrm{O}$

Table 3. Chemical Composition of ZSM-5 Film Formed on the Teflon Vessel from the Sintered Malaysia and New Zealand Kaolin by Hydrothermal Reaction

\begin{tabular}{|c|c|c|c|c|}
\hline \multirow{2}{*}{$\begin{array}{c}\text { Oxides } \\
(\text { mass\%) }\end{array}$} & \multicolumn{2}{|c|}{ Malaysia kaolin } & \multicolumn{2}{|c|}{ New Zealand kaolin } \\
\hline & ZSM-5 film (1) & ZSM-5 film (2) & ZSM-5 film (3) & ZSM-5 film (4) \\
\hline Loss of Ig. & 11.44 & 11.21 & 10.52 & 9.03 \\
\hline $\mathrm{SiO}_{2}$ & 80.50 & 79.69 & 86.64 & 86.00 \\
\hline $\mathrm{Al}_{2} \mathrm{O}_{3}$ & 5.44 & 6.22 & 1.88 & 3.35 \\
\hline $\mathrm{Fe}_{2} \mathrm{O}_{3}$ & 0.07 & 0.04 & 0.19 & 0.15 \\
\hline $\mathrm{TiO}_{2}$ & tr. & tr. & 0.07 & 0.06 \\
\hline $\mathrm{CaO}$ & 0.19 & 0.13 & 0.03 & 0.02 \\
\hline MgO & 0.03 & 0.01 & tr. & tr. \\
\hline $\mathrm{Na}_{2} \mathrm{O}$ & 1.51 & 2.20 & 0.66 & 1.65 \\
\hline $\mathbf{K}_{2} \mathbf{O}$ & 0.86 & 0.69 & 0.01 & 0.02 \\
\hline \multicolumn{5}{|l|}{ Molar ratio } \\
\hline $\mathrm{SiO}_{2} / \mathrm{Al}_{2} \mathrm{O}_{3}$ & 25.0 & 21.7 & $78.8^{11)}$ & $43.6^{11)}$ \\
\hline
\end{tabular}

Synthesis conditions:

ZSM-5 film (1) $100 \mathrm{SiO}_{2}: 12.8 \mathrm{NaOH}: 5 \mathrm{TPABr}: 2800 \mathrm{H}_{2} \mathrm{O}$ at $160^{\circ} \mathrm{C}$ for 14 days ZSM-5 film (2) $100 \mathrm{SiO}_{2}: 25.5 \mathrm{NaOH}: 5 \mathrm{TPABr}: 2800 \mathrm{H}_{2} \mathrm{O}$ at $160^{\circ} \mathrm{C}$ for 7 days ZSM-5 film (3) $100 \mathrm{SiO}_{2}: 12.8 \mathrm{NaOH}: 5 \mathrm{TPABr}: 2800 \mathrm{H}_{2} \mathrm{O}$ at $190^{\circ} \mathrm{C}$ for 14 days ZSM-5 film (4) $100 \mathrm{SiO}_{2}: 25.5 \mathrm{NaOH}: 5 \mathrm{TPABr}: 2800 \mathrm{H}_{2} \mathrm{O}$ at $190^{\circ} \mathrm{C}$ for 14 days
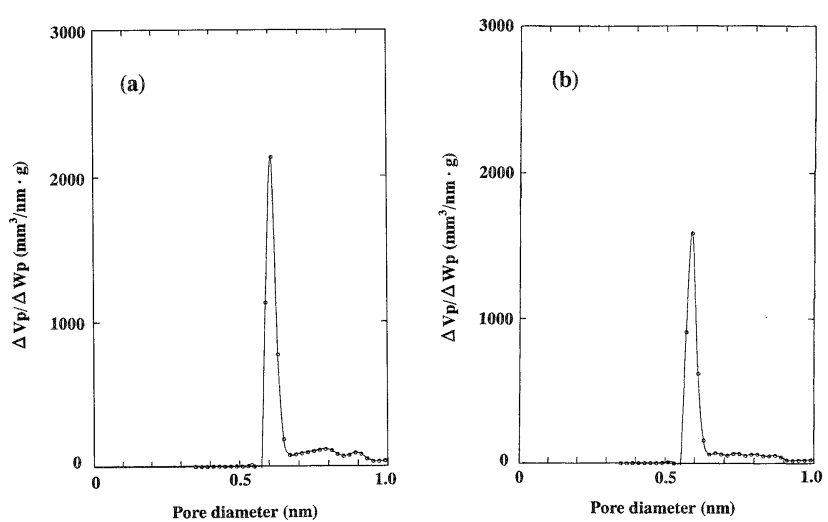

Fig. 6. Pore-size distribution of ZSM-5 zeolite (a) film formed on the Teflon vessel at $160^{\circ} \mathrm{C}$ for $7 \mathrm{~d}$ with a composition of $100 \mathrm{SiO}_{2}$ : $25.5 \mathrm{NaOH}: 5 \mathrm{TPABr}: 2800 \mathrm{H}_{2} \mathrm{O}$ and (b) the commercial ZSM-5 powder.

type ZSM-5 films formed on the honeycomb and the Teflon vessel.

Table 3 shows the chemical composition of ZSM-5 films on the Teflon vessel prepared from Malaysia kaolin and New Zealand kaolin. The samples were calcined at $1000^{\circ} \mathrm{C}$. In our previous study, ${ }^{13)} \mathrm{SiO}_{2}: \mathrm{Al}_{2} \mathrm{O}_{3}$ molar ratio of $\mathrm{ZSM}-5$ film prepared from the sintered New Zealand kaolin could be controlled by hydrothermal conditions such as the concentration of $\mathrm{NaOH}$ and reaction time, and the ratio was changed from 43.6 to 78.8. In the case of Malaysia kaolin, $\mathrm{SiO}_{2}: \mathrm{Al}_{2} \mathrm{O}_{3}$ molar ratio of $\mathrm{ZSM}-5$ film changed from 21.7 to 25.0 and the contents of $\mathrm{Na}_{2} \mathrm{O}$ was 1.51 to 2.20 mass $\%$. $\mathrm{SiO}_{2}: \mathrm{Al}_{2} \mathrm{O}_{3}$ molar ratio of $\mathrm{ZSM}-5$ film from Malaysia kaolin was lower than that of New Zealand kaolin. As mentioned in Section $3.1,6$ to 9 mass \% of unreacted aluminum source which existed in the silica-glass of the sintered Malaysia kaolin at $1450^{\circ} \mathrm{C}$ was dissolved into the liquid, and then incorporated into the ZSM-5 zeolite framework during its recrystallization and hence the $\mathrm{SiO}_{2} / \mathrm{Al}_{2} \mathrm{O}_{3}$ ratio of the ZSM-5 reported here is lower than that of the ZSM-5 reported previously from New Zealand kaolin. ${ }^{13)}$

\section{Conclusions}

In this study, a kaolin honeycomb sintered at $1450^{\circ} \mathrm{C}$ was used to produce a novel microporous-macroporous composite by hydrothermal treatment with $\mathrm{NaOH}$, TPABr, and deionized water at $160^{\circ} \mathrm{C}$ for 2 to $14 \mathrm{~d}$. The silica-glass in the sintered kaolin was used as a source for ZSM-5 zeolite. The effects of hydrothermal conditions on the formation of the composite and its properties were investigated. ZSM- 5 type zeolite crystals were formed in-situ on the honeycomb and on the Teflon vessel of the hydrothermal reactor by the dissolution of silica-glass from the kaolin at $160^{\circ} \mathrm{C}$ for 2 to $14 \mathrm{~d}$. By controlling the dissolution and recrystallization of the 
silica-glass, a continuous ZSM-5 film, 50 to $80 \mu \mathrm{m}$ thick, was formed on the porous mullite honeycomb. The surface area and average pore diameter of ZSM-5 film were $250-270 \mathrm{~m}^{2} /$ $\mathrm{g}$ and $0.61 \mathrm{~nm}$, respectively. By using Malaysia kaolin which contained higher $\mathrm{Na}_{2} \mathrm{O}$ and $\mathrm{K}_{2} \mathrm{O}$ contents, the sintering temperature of kaolin and hydrothermal temperature and time of ZSM-5 formation were reduced.

\section{References}

1) Kokotailo, G. T., Lawton, S. L., Olson, D. H. and Meier, W M., Nature (London), 272, 437 (1978).

2) Olson, D. H., Kokotailo, G. T., Lawton, S. L. and Meier, W. M., J. Phys. Chem., 85, 2238 (1981).

3) Hamada, H., Kintachi, Y., Sasaki, M., Ito, T. and Tabata, M., Appl. Catal., 64, L1-L4 (1990).

4) Iwamoto, M. and Hamada, H., Catal. Today, 50, 57-71 (1991).

5) Shu, J., Adont, A. and Grandjean, B. P. A., Ind. Eng. Chem. Res., 38, 3860-67 (1999).
6) Keil, F. J., Hinderer, J. and Garayhi, A. R., Catal. Today, 50, 637-50 (1999)

7) Jia, M.-D., Cen, B., Nobl, R. D. and Falconer, J. L., J. Membr. Sci., 90, 1-10 (1994).

8) Kusakabe, K., Yoneshige, S., Murata, A. and Morooka, S., J. Membr. Sci., 116, 39-46 (1996).

9) Bein, T., Chem. Mater., 8, 1636-53 (1996).

10) Mizukami, F., Stud. Surf. Sci. Catal., 125, 1-12 (1999).

11) Tuan, V. A., Falconer, J. L. and Noble, R. D., Ind. Eng. Chem. Res., 38, 3635-46 (1999).

12) Komarneni, S., Katsuki, H. and Furuta, S., J. Chem. Mater., 8, 2327-29 (1998).

13) Katsuki, H., Furuta, S. and Komarneni, S., J. Am. Ceram. Soc., 83, 1093-97 (2000).

14) Katsuki, H., Furuta, S., Ichinose, H. and Nakao, H., J. Ceram. Soc. Japan (Seramikkusu Ronbunshi), 96, 1081-86 (1988) [in Japanese].

15) Campos, T. W., Santos, H. D. S. and Santos, P. D. S., J. Am. Ceram. Soc., 59, 357-60 (1976). 